Article

\title{
Redefining Secondary Forests in the Mexican Forest Code: Implications for Management, Restoration, and Conservation
}

\author{
Francisco J. Román-Dañobeytia ${ }^{1,2, *}$, Samuel I. Levy-Tacher ${ }^{3}$, Pedro Macario-Mendoza ${ }^{4}$ and \\ José Zúñiga-Morales ${ }^{5}$
}

1 Center for Latin American Studies, University of Florida, Gainesville, FL 32611, USA

2 Madre de Dios Consortium, Puerto Maldonado, Madre de Dios 17001, Peru

3 El Colegio de la Frontera Sur, ECOSUR, San Cristóbal de las Casas, Chiapas 29290, Mexico; E-Mail: slevy@ecosur.mx

4 El Colegio de la Frontera Sur, ECOSUR, Chetumal, Quintana Roo 77900, Mexico; E-Mail: pmacario@ecosur.mx

5 Comisión de Áreas Naturales Protegidas, Reserva de la Biósfera Calakmul, Zoh-Laguna, Calakmul, Campeche 24644, Mexico; E-Mail: zuma10@hotmail.com

* Author to whom correspondence should be addressed; E-Mail: fromn76@gmail.com; Tel.: +51-940132696.

Received: 17 December 2013; in revised form: 14 May 2014 / Accepted: 15 May 2014 / Published: 21 May 2014

\begin{abstract}
The Mexican Forest Code establishes structural reference values to differentiate between secondary and old-growth forests and requires a management plan when secondary forests become old-growth and potentially harvestable forests. The implications of this regulation for forest management, restoration, and conservation were assessed in the context of the Calakmul Biosphere Reserve, which is located in the Yucatan Peninsula. The basal area and stem density thresholds currently used by the legislation to differentiate old-growth from secondary forests are $4 \mathrm{~m}^{2} /$ ha and 15 trees/ha (trees with a diameter at breast height of $>25 \mathrm{~cm}$ ); however, our research indicates that these values should be increased to $20 \mathrm{~m}^{2} / \mathrm{ha}$ and 100 trees/ha, respectively. Given that a management plan is required when secondary forests become old-growth forests, many landowners avoid forest-stand development by engaging slash-and-burn agriculture or cattle grazing. We present evidence that deforestation and land degradation may prevent the natural regeneration of late-successional tree species of high ecological and economic importance. Moreover, we discuss the results of this study in the light of an ongoing debate in the Yucatan Peninsula between policy makers, non-governmental organizations (NGOs),
\end{abstract}


landowners and researchers, regarding the modification of this regulation to redefine the concept of acahual (secondary forest) and to facilitate forest management and restoration with valuable timber tree species.

Keywords: Calakmul; chronosequence; functional groups; stakeholders; succession

\section{Introduction}

Forest governance can be described as the modus operandi by which officials and institutions acquire and exercise authority in the management of forest resources. Good forest governance is characterized by predictable, open, and informed policymaking based on transparent processes; a bureaucracy imbued with a professional ethos; an executive arm of government that is accountable for its actions; and a strong civil society that participates in decisions related to the sector $[1,2]$.

In 2003, the Mexican federal government published the Law for Sustainable Forestry Development (LSFD) with the primary objective of regulating and promoting the management, restoration, and conservation of forest ecosystems in the whole country [3]. This law authorizes timber harvesting in old-growth forest lands, and the establishment of commercial timber plantations in deforested lands. In 2005, the government published the regulation of this law [4]. The regulation determines the harvest potential based on specific minimum biomass/structural reference values that reflect the maturity of forest stands.

The definition of acahual (term used in Mexico for secondary forest) is only mentioned in the second point of the regulation and considers the native secondary vegetation that grows spontaneously in tropical forest lands that have previously been used for agriculture or cattle grazing. At this point, the regulation states that: (a) in evergreen or semi-evergreen forests, secondary vegetation is considered as those stands with less than 15 trees per hectare with a diameter at breast height (dbh) greater than $25 \mathrm{~cm}$, or with a basal area less than $4 \mathrm{~m}^{2} /$ ha; and (b) in dry forests, secondary vegetation is considered as those stands with less than 15 trees per hectare with dbh greater than $10 \mathrm{~cm}$, or with a basal area less than $2 \mathrm{~m}^{2} /$ ha [4].

In Mexico, the dominant vegetation communities are temperate forests, mostly Pinus and Quercus associations [5]. Therefore, it is possible that the LSFD and its regulation were developed based on the characteristics of these ecosystems, which are also the target of most of the commercial forestry in the country (65.3\%) [6]. However, in the view of scientists and stakeholders from the Mexican tropical areas, this legislation is not sufficiently flexible to allow regional variations in best practice that would encourage innovation and experimentation. This is the case in the Yucatan Peninsula, an important source of tropical forest and non-forest products for the rest of the country. The authorities, ecologists, and landowners of this region have initiated a dialogue to review the implications of the LSFD for forest management, restoration, and conservation.

The Yucatan Peninsula encompasses the largest expanse of seasonal deciduous semi-evergreen tropical forest in Mexico, forming a complex and biodiversity-rich environmental gradient between the drier north of the peninsula and the humid Peten region in Guatemala [7]. Forest surveys performed in the Yucatan Peninsula have demonstrated the importance of the traditional slash-and-burn agriculture 
for forest regeneration, the recovery of soil fertility and the supply of secondary forest products (e.g., wood, construction materials, textiles, food, medicines, and tanning) that are vital for its rural economy [8,9]. In addition, tourism development in the Mexican Caribbean has increased the demand for palm leaves and round wood from secondary forests $(<25 \mathrm{~cm}$ diameter at breast height, $\mathrm{dbh}$ ), which are widely used for the construction of lodges and play a key role on the marketing of this tourism destination [10].

The basis for traditional secondary forest use and management in the Yucatan peninsula is tropical swidden agriculture (variously called shifting cultivation, slash-and-burn agriculture, or, in Mesoamerica, the milpa). Like most other tropical swidden systems, that of the peninsular Mayans centers on felling primary or secondary forest, burning the dried cuttings, and planting selected species in the clearing. Mayans plant and harvest a milpa for two to five consecutive years, then plant the area in tree crops and extracts fruit, rubber, and cordage as the fallowed area regenerates into secondary forest. When regrowth reaches a height of four to seven meters (usually within five to seven years), they clear and burn the area for a second round of cultivation, or allow it to regenerate into secondary forest, a process which requires approximately twenty years of fallowing [8,9].

In this study, we evaluated the accuracy of the biomass/structural reference values of the LSFD and its regulation for differentiating secondary from old-growth forests, and assessed whether they may be preventing the traditional use, management, and restoration of secondary forests and threatening the conservation of biodiversity in the Yucatan Peninsula. We also present our results in the light of an ongoing debate between the authorities, scientists, and practitioners of the Yucatan Peninsula to assess the implications of the current legislation on forest management, restoration, and conservation.

\section{Materials and Methods}

\subsection{Study Area}

The implications of the LSFD for forest management and conservation were assessed in the context of the Calakmul Biosphere Reserve (CBR), which is located in the state of Campeche, Yucatan Peninsula, Mexico (Figure 1). The CBR covers an area of 723,185 ha and is the largest tropical reserve in the country. Its topography is flat and smooth and its altitude varies from 260 to $385 \mathrm{~m}$ above sea level [11]. The climate is warm subtropical with a mean annual temperature of $24.6^{\circ} \mathrm{C}$ and a mean annual rainfall of $1076 \mathrm{~mm}$. Soils are shallow, calcareous, and highly permeable because of a high organic matter content and an underlying limestone bedrock [9].

Semi-evergreen forests cover most of the surface of the reserve. These are forests with trees reaching $15-25 \mathrm{~m}$ in height, $25 \%-50 \%$ of which lose their leaves during the dry season. The flora of Calakmul includes $\sim 390$ genera and 1500 species, 10\% of which are endemic. The representative tree species of this type of forests are guayacán (Guaiacum sanctum), jobillo (Astronium graveolens), chicle (Manilkara zapota), ramón (Brosimum alicastrum), chakah (Bursera simaruba), and guarumo (Cecropia obtusifolia) [12]. 
Figure 1. Map of the study region in Southeastern Mexico, showing the location of the 50 forest plots sampled.

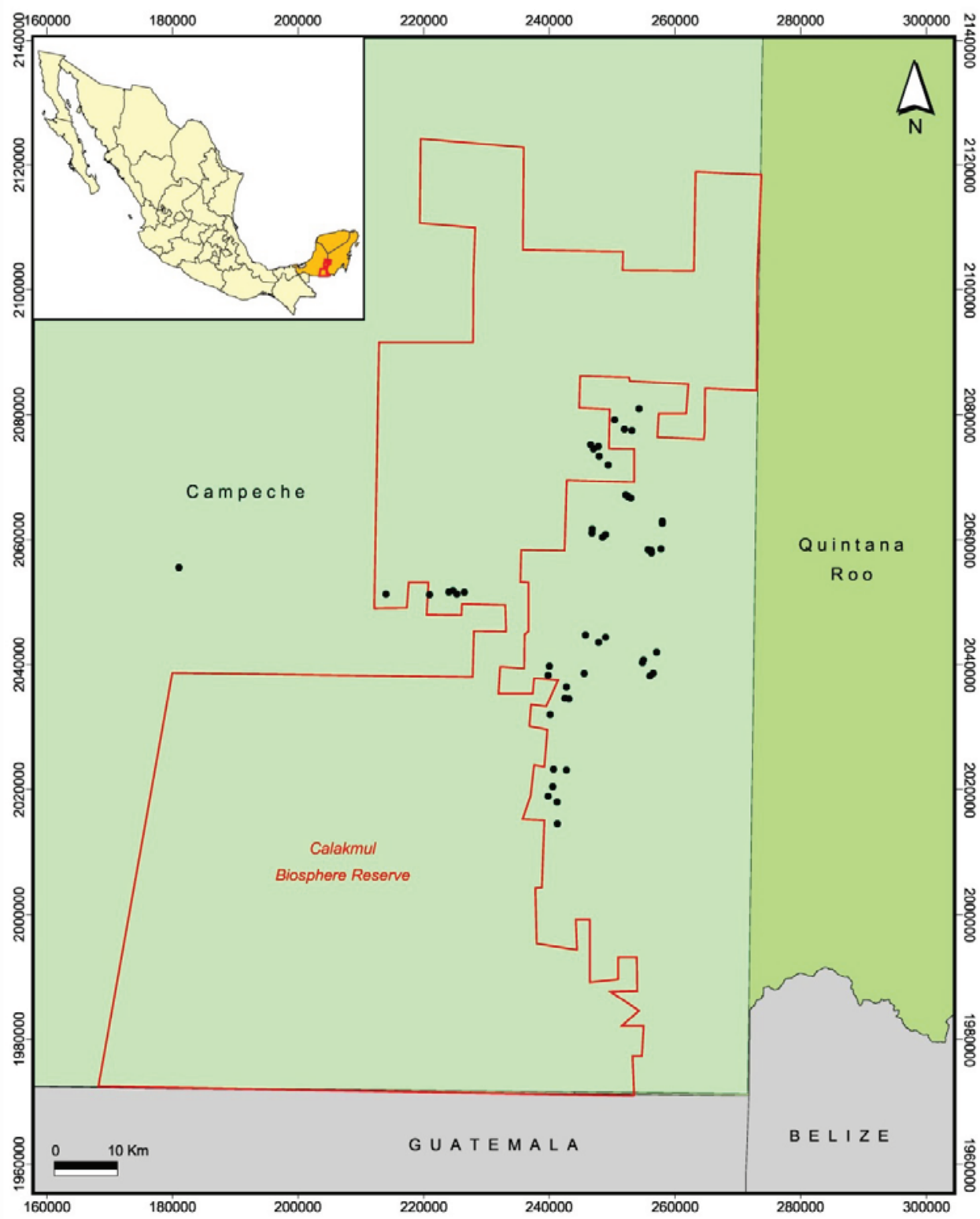

Land tenure in the reserve is $49.6 \%$ communal, $48.4 \%$ property of the nation, and $2 \%$ privately owned [13]. The people who live within the reserve came from the states of Tabasco, Veracruz, Chiapas, and Michoacan, and their main activities involve slash-and-burn agriculture, cattle grazing and the harvesting of secondary forests [7]. These activities are complementary within the traditional (indigenous) system of shifting cultivation, in which managing forest fallows and second-growth forests is considered as a component of an integral agricultural system that relies on forest resilience [8,9].

\subsection{Workshops}

Between 2011 and 2013, representatives of the CBR funded and convened a total of 12 workshops to promote a multi-sectorial dialogue aimed at evaluating the potential implications of the LSFD and 
its regulation for traditional secondary forest management, as well as for the conservation of the region's biodiversity.

The participants of the workshops included representatives of the three broad groups that have a stake in ensuring good governance in the forest sector: (a) government: sub-national and national representatives of forest agencies and other departments and ministries; (b) civil society: representatives of community groups and social and environmental non-governmental organizations; and (c) the academic sector, represented by research specialists in forest ecology and management.

Representatives of the CBR encouraged scientists from El Colegio de la Frontera Sur to evaluate the accuracy of the forest ecological criteria stated in the regulation of LSFD. For this purpose, we conducted: (1) a review of the forest successional studies performed in the study region and in other similar tropical forests; (2) a comprehensive field sampling on forest successional development in the study area; and (3) an evaluation of the potential risks for biodiversity conservation that could stem from the implementation of the LSFD and its regulation.

\subsection{Field Sampling}

To assess the reliability of the biomass/structural reference values established by the regulation of the LSFD for differentiating old-growth from secondary forests in the context of the semi-evergreen tropical forests of the Yucatan Peninsula, we performed vegetation assessments in the CBR using a chronosequence approach. Field data were recorded during plant surveys conducted during 2012. The surveys were based on a stratified random sampling design with a total of 50 sampling plots in five stages of forest succession (10 plots per age class), i.e., 3-6, 9-11, 14-16, 19-21, and more than 50 years with no evidence of recent clearing, burning, or extractive human activities. The local authorities and informants from local communities helped to identify the tree species present in the plots, their main uses, and the land-use history of the different sites sampled.

After the identification of forest stands at different fallow intervals, we sampled 10 plots of $500 \mathrm{~m}^{2}$ per age class. Using calipers, we measured all stems that were $>2 \mathrm{~cm} \mathrm{dbh}$. The source of the species regeneration (seed or regrowth) was also recorded in a field notebook. Samples of the specimens were collected and deposited in the herbarium of El Colegio de la Frontera Sur, Chetumal headquarters. For species identification, we used dichotomous botanical keys, existing floristic lists for the study area [14], and sample contrast with herbarium specimens.

\subsection{Data Analysis}

Differences in basal area and stem density as a function of age were tested, via one-way analysis of variance (ANOVA). Tukey's multiple comparison procedure was applied if statistical differences were detected $(p<0.05)$. To comply with normality assumptions prior to ANOVA, stem density was $\log _{10}$ transformed [15]. Depending on species basal area across forest age classes, we classified species into successional groups, such as pioneer, persistent non-dominant, persistent dominant, and late-successional species [16]. We performed all statistical analyses and plots using the IBM SPSS Statistics processor, version 21.0. 


\section{Results and Discussion}

\subsection{Workshop Assessment}

Workshops brought together 67 stakeholders from 10 organizations (including the government, civil society, and academia) with the aim of identifying possible inconsistencies and deliverable actions to improve the LSFD and its regulation. In general, the most recurrent problems in the legislation identified by the participants were: (1) the traditional use and management of secondary forests is not taken into consideration and has been relegated to illegality given that the reference values for distinguishing secondary from old-growth harvestable forests are controversial; (2) landowners prefer to dedicate resources to agriculture or cattle grazing than to forest management or restoration, to avoid complying with the costly management plans that are required by the legislation; and (3) the expansion of deforestation and land degradation may prevent the regeneration of slow-growing tree species of high economic value. As deliverable actions, participants agreed on the need to develop a reform proposal that should include: (1) the recognition of traditional secondary forest management for the provision of construction materials and other potential new forest products; (2) the modification of the reference values for distinguishing old-growth from secondary forests based on scientific data on the regional forest ecology; and (3) the development of a regional compensatory mechanism that supports forest restoration in harvested areas, especially regarding threatened species of high ecological and economic value.

\subsection{Forest Successional Trends}

In agreement with many studies on post agricultural tropical forest succession, our review of forest succession in the region indicated that basal area increases with time since abandonment, while stem density (stems $>1$ or $2 \mathrm{~cm}$ dbh) decreases with fallow age (Table 1).

In our study, basal area $(\mathrm{F}=31.4, p<0.001)$ and stem density $(\mathrm{F}=67.0, p<0.001)$ varied significantly among age classes. The minimum and maximum basal area values were 3.3 and $32.6 \mathrm{~m}^{2} /$ ha, respectively, and increased significantly with fallow age. These results reconfirmed that the reference value of $4 \mathrm{~m}^{2}$ /ha stipulated by the regulation of the LSFD was too low to distinguish old-growth from secondary forests appropriately, as young regenerating and secondary forest stands were all being considered as old-growth forests (Figure 2).

Stem density ( $>2 \mathrm{~cm} \mathrm{dbh}$ ) decreased significantly with age, from approximately 22,000 in the age class of 5 years to 4000 in the age class of 50 years (Figure 2). In contrast, stem density ( $>25 \mathrm{~cm} \mathrm{dbh}$ ) increased significantly with age, from zero in the youngest age class ( 5 years) to 218 in the age class of 50 years. These results indicate the presence of a large amount of thin stems in young stages and larger trees in more advanced successional stages. The reference value on stem density $(15$ trees $>25 \mathrm{~cm} \mathrm{dbh}$ per hectare) of the regulation is also too low to reflect the structural differences between secondary and old-growth forests (Figure 2). 
Table 1. Review of forest structural reference values among successional studies conducted in the Yucatan Peninsula and other similar tropical forests.

\begin{tabular}{|c|c|c|c|c|c|}
\hline & $\begin{array}{l}\text { Young Forest } \\
\text { (<4-6 years) }\end{array}$ & $\begin{array}{c}\text { Old-Growth Forest } \\
(30-50 \text { years })\end{array}$ & Forest Type & Location & Reference \\
\hline \multirow{6}{*}{$\begin{array}{l}\text { Basal Area } \\
\left(\mathbf{m}^{2} / \mathbf{h a}\right)\end{array}$} & 7.6 & 38.0 & Semi-evergreen & Southern Yucatan & [9] \\
\hline & 7.5 & 17.0 & Semi-evergreen & Eastern Yucatan & [17] \\
\hline & 7.6 & 22.7 & Semi-evergreen & Southern Yucatan & This Study \\
\hline & 10.0 & 31.2 & Seasonally dry & Central Yucatan & {$[18]$} \\
\hline & 5.0 & 22.5 & Seasonally dry & Oaxaca & [19] \\
\hline & 15.0 & 28.0 & Seasonally dry & Bolivia & {$[20]$} \\
\hline \multirow{5}{*}{$\begin{array}{l}\text { Stem Density } \\
\text { (\#/ha) }\end{array}$} & $20,000(>1 \mathrm{~cm} \mathrm{dbh})$ & $10,000(>1 \mathrm{~cm} \mathrm{dbh})$ & Semi-evergreen & Southern Yucatan & [9] \\
\hline & $22,000(>2 \mathrm{~cm} \mathrm{dbh})$ & $4000(>2 \mathrm{~cm} \mathrm{dbh})$ & Semi-evergreen & Southern Yucatan & This Study \\
\hline & $6638(>2 \mathrm{~cm} \mathrm{dbh})$ & $6644(>2 \mathrm{~cm} \mathrm{dbh})$ & Seasonally dry & Central Yucatan & [18] \\
\hline & $5000(>1 \mathrm{~cm} \mathrm{dbh})$ & $4500(>1 \mathrm{~cm} \mathrm{dbh})$ & Seasonally dry & Oaxaca & [19] \\
\hline & $8000(>2 \mathrm{~m}$ tall $)$ & $4000(>2 \mathrm{~m}$ tall $)$ & Seasonally dry & Bolivia & [20] \\
\hline
\end{tabular}

\subsection{Potential Risks for Biodiversity Conservation}

Our field sampling also revealed that certain species might be threatened by the implementation of the LSFD and its regulation. The fact that landowners prefer to engage in agriculture and cattle grazing instead of forest management (as mentioned during the workshops) will lead to an increase in deforestation and land degradation. In this scenario, the natural regeneration of late-successional native tree species could be seriously threatened, given that, in our study, these species were absent in the early stages of succession (first 5-10 years); coexistence of late-successional species with pioneer and persistent species was only evident in more advanced successional stages (15-50 years) (Figure 3). Late-successional species are usually long-lived and shade-tolerant and produce large fruits and seeds that are dispersed mainly by mammals [21,22]. The representative late-successional species found in our sampling included Brosimum alicastrum, Pimenta dioica, Talisia olivaeformis, and Manilkara sapota.

In contrast, pioneer species were dominant in the early stages of succession (first 5-10 years) and their abundance decreased progressively with time (Figure 3). Pioneer species are those that are able to colonize open areas; they are short-lived, fast-growing, and shade-intolerant species that produce small seeds that are dispersed mostly by the wind and birds [21,22]. The pioneer species found in our study included Trema micrantha, Cecropia peltata, Solanum erianthum, and Hampea trilobata.

In addition, persistent species were nearly constantly present throughout forest succession (Figure 3). The adaptation feature of persistent species to resprout from stumps (Table 2) enables them to survive disturbances (i.e., slash-and-burn agriculture, hurricanes, and fire) and represent a high percentage of the initial floristic composition [23]. This allows the development of large-sized individuals over short periods, unlike what would happen if these species were established from seeds $[9,24]$ as in the case of late-successional species (Table 2). In our study, persistent species were divided into dominant (e.g., Bursera simaruba, Malmea depressa, Pouteria campechiana, and Dendropanax arboreus) and non-dominant (e.g., Guettarda combsii, Simarouba glauca, Piscidia piscipula, Coccoloba spicata) species, depending on their basal area values across the successional stages. 
Figure 2. Basal area and stem density in forest stands of Southern Yucatan, with abandonment times ranging from 3 to $>50$ years. The red dashed lines represent the current reference values established by the regulation of the Law for Sustainable Forestry Development (LSFD), whereas the blue dashed lines represent accurate science-based reference values. The different letters placed above the error bars indicate statistically significant differences (analysis of variance (ANOVA), Tukey's test, $p<0.05$ ).

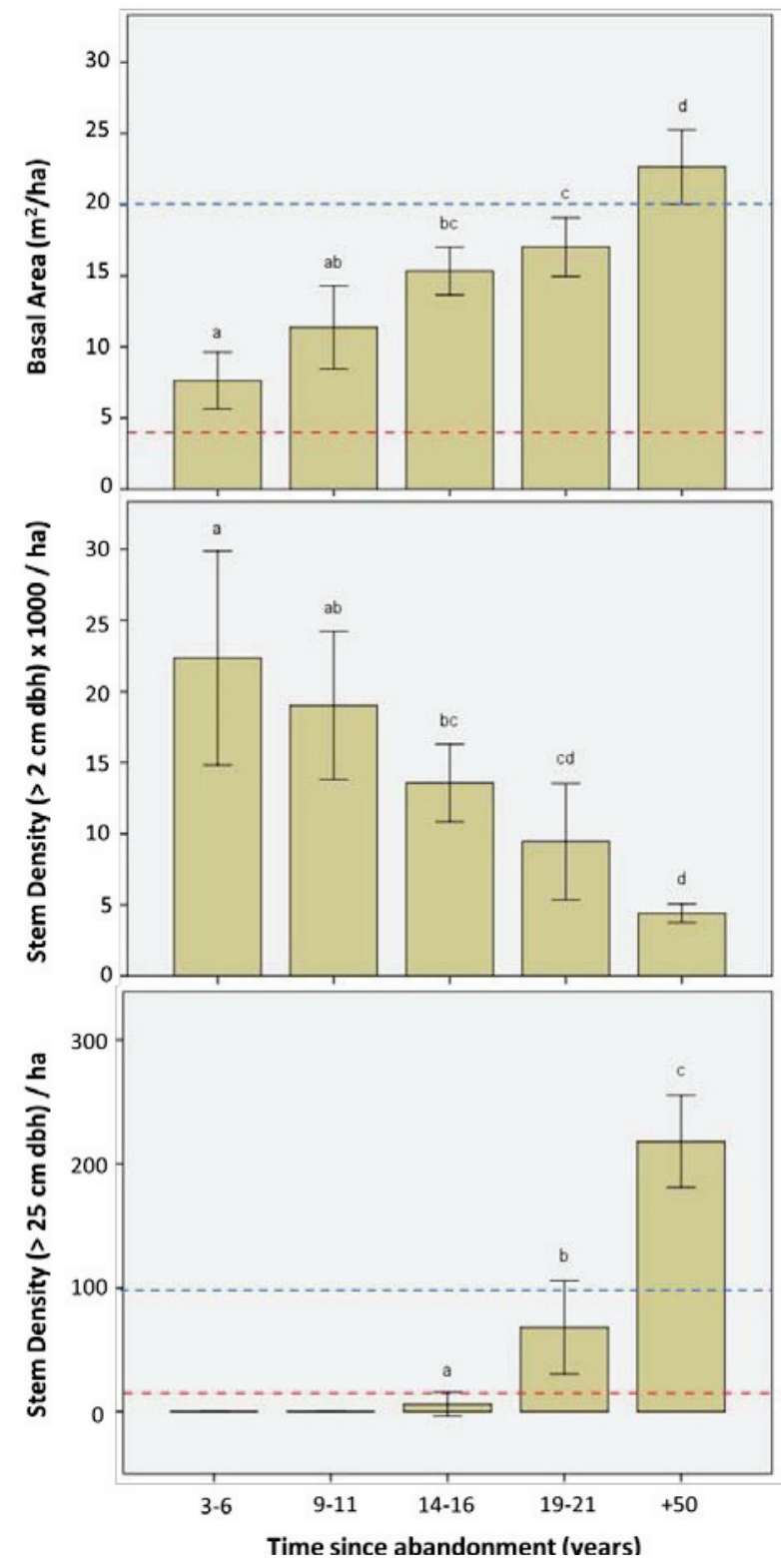

Table 2. Number of species from different successional groups that regenerate from seeds and/or stump regrowth (data from the current study).

\begin{tabular}{ccc}
\hline \multirow{2}{*}{ Successional Groups } & \multicolumn{2}{c}{ Source of Regeneration } \\
\cline { 2 - 3 } & Stump Regrowth & Seeds \\
\hline Pioneer Species & 19 & 6 \\
Persistent Non-dominant Species & 37 & 5 \\
Persistent Dominant Species & 15 & 1 \\
Late-Successional Species & 3 & 14 \\
\hline
\end{tabular}


Figure 3. Basal area within successional groups across seasonal semi-evergreen forest stands, with abandonment times ranging from 5 to 50 years in the Yucatan Peninsula region.

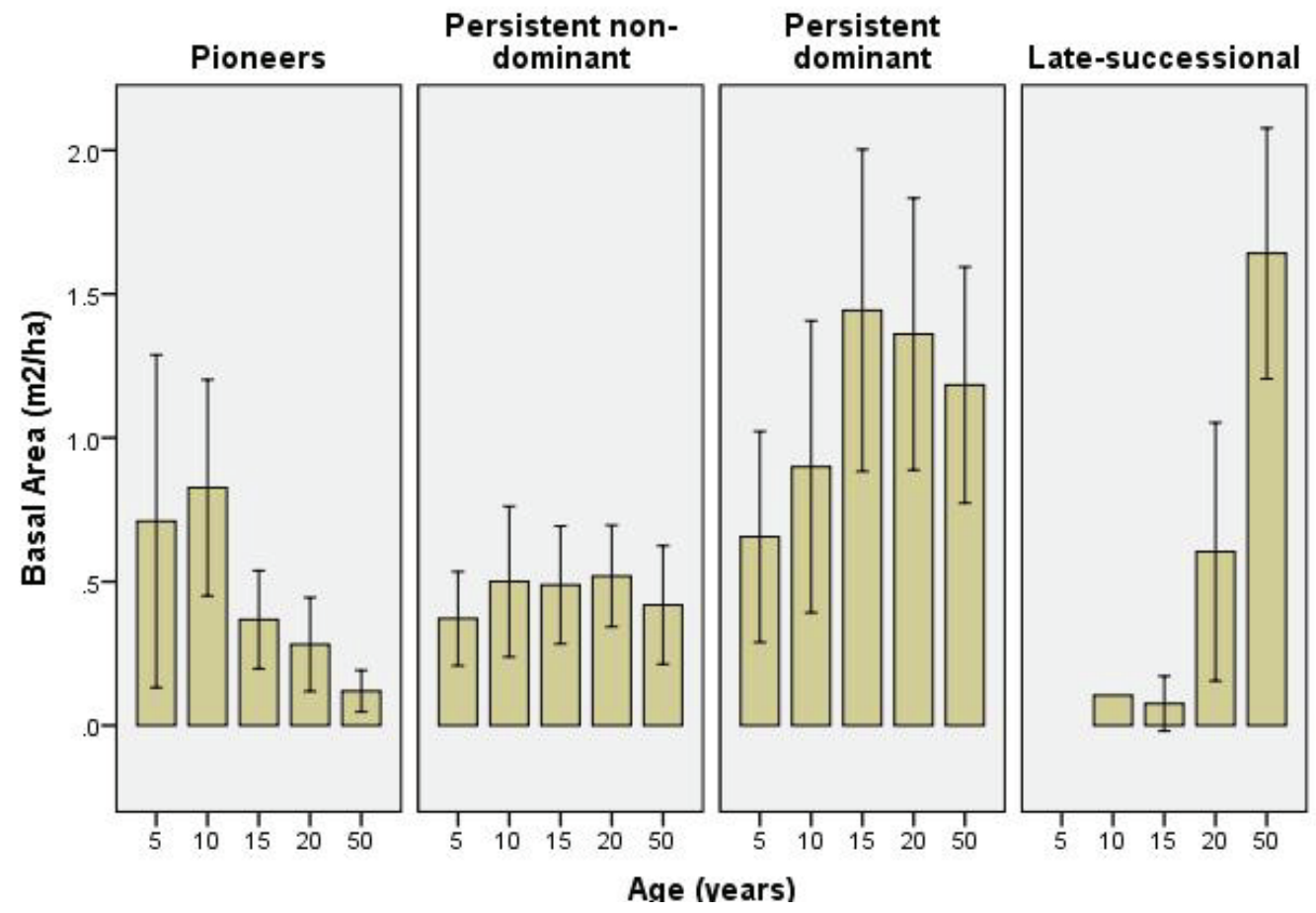

\subsection{Implications for Management, Restoration, and Conservation}

One of the main problems detected by stakeholders regarding the LSFD and its regulation concerns the ignorance of the harvesting potential of secondary forests (trees $<25 \mathrm{~cm} \mathrm{dbh}$ ) for rural construction in Mayan communities and for the building of touristic rustic structures in the Mexican Caribbean. Also, non-timber forest products obtained from secondary forests such as the native palm species used for roofing (e.g. Sabal yapa and Sabal mauritiiformis), handicrafts (e.g. Cryosophila argentea and Desmoncus quasillarius), and ornamental (e.g. Chamaedorea seifrizii) have been a successful source of income for the rural communities of the Yucatan Peninsula, particularly as an alternative to high-value woods with larger diameters. However, the obligation to implement forest management plans (as those needed for large timber volumes) would render this activity non-viable economically. This requirement means that many landowners fail to have the necessary documentation for the marketing of these forest products. Nonetheless, all workshop participants agreed on the need of regulation of this activity to promote its legality and the conservation of Mayan traditional ecological knowledge.

Experiences worldwide have demonstrated that excessive regulations may entail prohibitively high transaction costs regarding legal operations, rendering adherence to the law impractical for many forest users [1,2]. This is particularly the case for community-based organizations from Southeast Mexico, which are often poorly equipped to comply with convoluted administrative procedures. Although there is strong evidence of a deep Mayan traditional ecological knowledge related to the sustainable use of secondary forests in the Yucatan Peninsula [25,26], this has been disregarded in the LSFD and its regulation, which have considered native forests as those that develop naturally without human 
intervention [3,4]. However, there is ample evidence of forest recovery after the slash-and-burn Mayan agricultural practice [8,9], which has shaped the Yucatecan forest landscape for centuries [23,27].

As a broad boundary between cultivated field and primary forest, the acahual contains a species structure and biomass distribution that differs from either field or forest, which facilitates the natural regeneration of many useful plants and late-successional tree species [25]. However, the acahual also plays an important role as a managed wildlife area since it contains a number of food sources not found in the forest that attract many animal species [28]. In fact, certain species seem to have adapted specifically to exploit this human-made niche, for they are found in larger numbers in acahual-bearing areas than they are in totally wild situations $[7,10]$.

\subsection{Future Perspectives}

Our data on basal area and stem density were consistent with other studies that were conducted in similar forest types [29,30] and demonstrated that the reference values stipulated in the current Mexican forest code do not apply to the tropical forests of the Yucatan peninsula. Therefore, the values of forest structural criteria in the legislation should be increased, as suggested above. Forest reference values should be established based on reliable data and validated using participatory processes among users before publishing [2]. Otherwise, inconsistencies will lead to misinterpretations and failure to accomplish the goals of the law.

Our study also showed that the natural regeneration of late-successional species might be seriously threatened by the current problems detected in the LSFD and its regulation. Despite the expected rapid recovery of Yucatan forests because of their resprouting capability after clear-cutting activities [23], the establishment and further development of species that are key for long-term ecosystem functioning, such as long-lived and shade-tolerant late-successional tree species, are particularly vulnerable to deforestation and land degradation [22,26]. The seed germination and growth of late-successional species require specific sub canopy conditions of long fallow; thus these species are absent in young regenerating stands [31]. If not, their absence could severely affect the structure, composition, and functioning of forests [32]. In the long term, increased deforestation and the dominance of young regenerating stands at a landscape scale may lead to the regeneration of pioneer or persistent species exclusively, driving the loss of many late-successional species of the regional species pool [33].

Although the traditional shifting cultivation usually restarts the process of cutting down the forest again, it is necessary to manage at least a fraction of the secondary forests to become old-growth forests and to support the regeneration of threatened late-successional species of high ecological and social value. Legal instruments that encourage environmental certification for industries appear to be helpful for funding forest management and restoration activities in rural communities of tropical countries [2,34]. Valuation via the promotion of the trading and selling of certified forest products and rewards for ecosystem services rendered (including carbon sequestration) can also help increase forest conservation [35,36]. Similarly, the capacity of the Southern Yucatan forests to provide critical ecosystem services to thousands of people and to generate jobs for the inhabitants of local communities via forest management and restoration can be improved by specific adjustments of the current Mexican Forest Code. 


\section{Conclusions}

The current forest structural reference values established by the regulation of the Mexican LSFD are controversial and do not apply to the tropical forests of the Yucatan, as they do not serve to differentiate between young regenerating, secondary, and old-growth forests appropriately. Moreover, the LSFD and its regulation disregard the traditional harvesting of secondary forests for rural construction, thus forcing small landowners to comply with management plans as if they were major timber producers. Although the stump regrowth of persistent species is important for forest regeneration after agricultural land use in the Yucatan peninsula, the diversity and coexistence of species from different successional groups is maximized in intermediate successional stages (about 20 years after abandonment). Late-successional species are particularly vulnerable to increased deforestation and the systematic clear cutting of young secondary forests, because of the specific conditions that are required for their regeneration, which can only be achieved through long fallow periods ( $>20$ years). The facilitation of participatory processes between the different stakeholders involved in local forestry allowed the review of the major problems of the LSFD and its regulation, as well as the implementation of a field sampling to evaluate the accuracy and implications of the forest ecological criteria of these legal instruments. To adjust the existing reference values, as well as to develop a consensual concept of secondary forests, both in the regulation and in the law itself, modifications should be accompanied by accessible and well-documented procedures, and by fiscal incentives to encourage voluntary investments in forest management and restoration.

\section{Acknowledgments}

We thank the members of the Regional Association of State Foresters and Etnobiología para la Conservación for technical field support. We also thank the Calakmul Biosphere Reserve for the funds provided for this study. We greatly appreciate the useful comments of the reviewers and editors of the Special Issue on the earlier drafts of this manuscript.

\section{Author Contributions}

Francisco Román led the general organization of the paper. Samuel Levy contributed information on species ecology and successional groups. Pedro Macario contributed to traditional secondary forest management and led the field sampling. José Zúñiga contributed specific information on Calakmul and led the organization of the workshops. All co-authors contributed to the general framework of the paper.

\section{Conflicts of Interest}

The authors declare no conflict of interest. 


\section{References}

1. Food and Agriculture Organization of the United Nations (FAO); International Tropical Timber Organization (ITTO). Forest Governance and Climate-Change Mitigation; Policy Brief, FAO/ITTO Initiative on Forest Law Compliance and Governance: Rome, Italy, 2009.

2. Aronson, J.; Brancalion, P.H.S.; Durigan, G.; Rodrigues, R.R.; Engel, V.L.; Tabarelli, M.; Torezan, J.M.D.; Gandolfi, S.; de Melo, A.C.G.; Kageyama, P.Y.; et al. What role should government regulation play in ecological restoration? Ongoing debate in Sao Paulo State, Brazil. Restor. Ecol. 2011, 19, 690-695.

3. Comisión Nacional Forestal (CONAFOR). Ley General de Desarrollo Forestal Sustentable; Diario Oficial de la Federación (25 Febrero): México D.F., Mexico, 2003. Available online: http://www.diputados.gob.mx/LeyesBiblio/pdf/259.pdf (accessed on 12 June 2013).

4. Comisión Nacional Forestal (CONAFOR). Reglamento de la Ley General de Desarrollo Forestal Sustentable; Diario Oficial de la Federación (21 Febrero): México D.F., Mexico, 2005. Available online: http://www.diputados.gob.mx/LeyesBiblio/regley/Reg_LGDFS.pdf (accessed on 12 June 2013).

5. Instituto Nacional de Estadística, Geografía e Informática (INEGI). Información Geográfica; INEGI: México D.F., Mexico, 2005.

6. Secretaría de Agricultura y Recursos Hidráulicos (SARH). Inventario Nacional Forestal Periódico (1992-1994); SARH: México DF, Mexico, 1994.

7. Vester, H.F.M.; Lawrence, D.; Eastman, J.R.; Turner, B.L., II; Calme, S.; Dickson, R.; Pozo, C.; Sangermano, F. Land change in the southern Yucatan and Calakmul Biosphere Reserve: Effects on habitat and biodiversity. Ecol. Appl. 2007, 17, 989-1003.

8. Levy-Tacher, S.I.; Aguirre-Rivera, J.R. El aprovechamiento agrícola intensivo de los Hubchés (Acahuales o comunidades secundarias) de Yucatán. Rev. Geogr. 2000, 28, 79-103.

9. Read, L.; Lawrence, D. Recovery of biomass following shifting cultivation in dry tropical forests of the Yucatan. Ecol. Appl. 2003, 13, 85-97.

10. Ellis, E.A.; Porter-Bolland, L. Is community-based forest management more effective than protected areas? A comparison of land use/land cover change in two neighboring study areas of the Central Yucatan Peninsula, Mexico. For. Ecol. Manag. 2008, 256, 1971-1983.

11. Instituto Nacional de Estadística, Geografía e Informática (INEGI). Campeche: Datos por Ejido y Comunidad Agraria. XI Censo General de Población y Vivienda, 1990; INEGI: Aguascalientes, México DF, Mexico, 1996.

12. Martínez, E.; Galindo-Leal, C. La vegetación de Calakmul, Campeche, México: Clasificación, descripción y distribución. Bol. Soc. Bot. Méx. 2002, 71, 7-32.

13. Sánchez-González, M.C. Calakmul, encuesta. Proyecto de Evaluación de Áreas Naturales Protegidas de México; Gómez-Pompa, A., Dirzo, R., Eds.; Secretaría de Desarrollo Social, Sedesol: México DF, Mexico, 1993.

14. Pennington, T.D.; Sarukhán, J. Árboles Tropicales de México, 3rd ed.; Universidad Nacional Autónoma de México y Fondo de Cultura Económica: México DF, Mexico, 2005.

15. Fry, J.C. Biological Data Analysis. A Practical Approach; Oxford University Press: Oxford, UK, 1993. 
16. Levy-Tacher, S.I.; Aguirre-Rivera, J.R. Successional pathways derived from different vegetation use patterns by Lacandon Mayan Indians. J. Sustain. Agric. 2005, 26, 49-82.

17. Urquiza-Haas, T.; Dolman, P.M.; Peres, C.A. Regional scale variation in forest structure and biomass in the Yucatan Peninsula, Mexico: Effects of forest disturbance. For. Ecol. Manag. 2007, 247, 80-90.

18. Hartter, J.; Lucas, C.; Gaughan, A.E.; Aranda, L.L. Detecting tropical dry forest succession in a shifting cultivation mosaic of the Yucatan Peninsula, Mexico. Appl. Geogr. 2008, 28, 134-149.

19. Lebrija-Trejos, E.; Pérez-García, E.A.; Meave, J.A.; Bongers, F.; Poorter, L. Functional traits and environmental filtering drive community assembly in a species-rich tropical landscape. Ecology 2010, 91, 386-398.

20. Kennard, D.K. Secondary forest succession in a tropical dry forest: Patterns of development across a 50-year chronosequence in lowland Bolivia. J. Trop. Ecol. 2002, 18, 53-66.

21. Whitmore, T.C. Canopy gaps and the two major groups of forest trees. Ecology 1989, 70, 536-538.

22. Gourlet-Fleury, S.; Blanc, L.; Picard, N.; Sist, P.; Dick, J.; Nasi, R.; Swaine, M.; Forni, E. Grouping species for predicting mixed tropical forest dynamics: Looking for a strategy. Ann. For. Sci. 2005, 62, 785-796.

23. Negreros-Castillo, P.; Hall, R.B. Sprouting capability of 17 tropical tree species after overstory removal in Quintana Roo, Mexico. For. Ecol. Manag. 2000, 126, 399-403.

24. Clarke, P.J.; Lawes, M.J.; Midgley, J.J.; Lamont, B.B.; Ojeda, F.; Burrows, G.E.; Enright, N.J.; Knox, K.J.E. Resprouting as a key functional trait: How buds, protection and resources drive persistence after fire. New Phytol. 2013, 197, 19-35.

25. Hernández-Xolocotzi, E.; Bello, E.; Levy-Tacher, S. La Milpa en Yucatán, un Sistema de Producción Agrícola Tradicional; Colegio de Postgraduados: Montecillos, México, 1995.

26. Hernandez-Stefanoni, J.L.; Dupuy, J.M. Effects of landscape patterns on species density and abundance of trees in a tropical subdeciduous forest of the Yucatan Peninsula. For. Ecol. Manag. 2008, 255, 3797-3805.

27. Zidar, C.; Elisens, W. Sacred giants: Depiction of Bombacoideae on Maya ceramics in Mexico, Guatemala, and Belize. Econ. Bot. 2009, 63, 119-129.

28. Nations, J.D.; Nigh, R.B. The evolutionary potential of Lacandon Maya sustained-yield tropical forest agriculture. Anthr. Res. 1980, 36, 1-30.

29. Guariguata, M.; Ostertag, R. Neotropical secondary forest succession: Changes in structural and functional characteristics. For. Eco. Manag. 2001, 148, 185-206.

30. Bonilla, M. Forest Recovery and Management Options in the Yucatan Peninsula, Mexico. Ph.D. Thesis, University of California, Santa Cruz, CA, USA, 2008.

31. Wright, S.J. Plant diversity in tropical forests: A review of mechanisms of species coexistence. Oecologia 2002, 130, 1-14.

32. Isbell, F.; Calcagno, V.; Hector, A.; Connolly, J.; Harpole, W.S.; Reich, P.B.; Scherer-Lorenzen, M.; Schmid, B.; Tilman, D.; van Ruijven, J.; et al. High plant diversity is needed to maintain ecosystem services. Nature 2011, 477, 199-203.

33. Martinez-Garza, C.; Howe, H.F. Restoring tropical diversity: Beating the time tax on species loss. J. Appl. Ecol. 2003, 40, 423-429. 
34. Rodrigues, R.R.; Gandolfi, S.; Nave, A.G.; Aronson, J.; Barreto, T.E.; Vidal, C.Y.; Brancalion, P.H. Large-scale ecological restoration of high-diversity tropical forests in SE Brazil. For. Ecol. Manag. 2011, 261, 1605-1613.

35. Alexander, S.; Nelson, C.; Aronson, J.; Lamb, D.; Martinez, D.; Harris, J.; Higgs, E.; Lewis, R.R., III; Finlayson, M.; Erwin, K.; et al. Opportunities and challenges for ecological restoration within REDD+. Restor. Ecol. 2011, 19, 683-689.

36. Wu, T.; Kim, Y.-S.; Hurteau, M.D. Investing in natural capital: Using economic incentives to overcome barriers to forest restoration. Restor. Ecol. 2011, 19, 441-445.

(C) 2014 by the authors; licensee MDPI, Basel, Switzerland. This article is an open access article distributed under the terms and conditions of the Creative Commons Attribution license (http://creativecommons.org/licenses/by/3.0/). 